\title{
4
}

\section{Cultural domains and the theory of customary environmentalism in Indigenous Australia}

\author{
Kim de Rijke, Richard Martin and David Trigger
}

\section{Introduction}

Under the long-term leadership of Professor Jon Altman, the Centre for Aboriginal Economic Policy Research (CAEPR) at The Australian National University has had an impressive publication output. The Centre has consistently focused on the important but challenging intersection of academic research and policy development relevant to Indigenous people in Australia. This paper engages with some of the intellectual concepts employed in the Centre's recent work, concentrating particularly on the volume edited by Jon Altman and Seán Kerins (2012) People on country: vital landscapes, Indigenous futures. The book promotes one of CAEPR's key pieces of recent policy advice: that Indigenous involvement in environmental work through ranger programs promotes improved environmental health as well as healthier human lifestyles, while bringing alternate forms of economic development for regional- and remote-living Indigenous people.

We offer some points of discussion to inform a respectful but robust debate about this proposition. Firstly, we focus on the scope of the research upon which some of the conclusions by Altman, Kerins, 
and others are based. Secondly, we pay attention to the two-way approach between Western science and Indigenous knowledge as it is promulgated by the authors, drawing on de Rijke's (2013) and Martin's (2013a) previously published reviews of People on country. We follow these discussions with a number of observations resulting from our own academic and applied work with Aboriginal people in the Gulf Country and southern Queensland.

While cognizant of the polemical nature of the debate about futures for Indigenous people in regional and remote Australia, we maintain the importance of a critical engagement with the literature and continued empirical research in this field. We come to the conclusion that the rigour of the Centre's current 'direct-action research' may be undermined by a political engagement that avoids critical discussion of fundamental concepts such as cultural domains, traditional knowledge and customary environmentalism, and call for further research into localised environmental knowledge and alternative development aspirations around Australia.

\section{Customary environmentalism in Aboriginal communities}

In People on country, a strong argument is made about the importance of Indigenous environmentalism and the customary economy across Australia. Such generalisations are particularly based on research in northern Australia (at Maningrida, Nhulunbuy, Yirrkala, Ngukurr and Kabulwarnamyo in Arnhem Land, and Borroloola in the Gulf Country) where classical Indigenous traditions have been retained the most (a counter-example from Guyra in northern New South Wales is also discussed). ${ }^{1}$ However, generalisations about the role of customary environmentalism and the customary economy more broadly are unconvincing in the absence of supporting empirical data obtained from a sufficiently broad range of locations across the country. It is problematic to use research findings based primarily on northern Australia as the basis for nation-wide generalisations and/or policy

1 Classical Indigenous traditions should not be regarded as unchanged, static practices and beliefs. Rather, the term is employed, where relevant, to indicate a significant degree of continuity in Indigenous traditions since colonisation. 
advice. Indeed, even in regions where classical Indigenous cultures appear strongest such as northern Australia, an adequate account of people's lives cannot neglect to describe the challenges to the reproduction of customary knowledge and practices. These include material and cultural attractions of the wider Australian society as well as the realities of socioeconomic inequality, structural discrimination, interpersonal violence, and related social crises (Sutton 2009).

An argument often posited in these discussions is the significance of bush foods for impoverished Indigenous people's diets. While such significance may well be found in some regions (e.g. O'Dea 1984, Scelza et al. 2014), it is important that relevant quantitative data across Australia is obtained. We realise the numerous difficulties associated with such a research project, but such empirical data is important if we wish to distinguish between the symbolic and dietary significance of bush foods in all regions of Australia. It is possible to elicit supportive commentary from Indigenous people in many settings regarding the significance of bush foods as 'income', country as a 'supermarket', and so on. But based on our own observations and discussions with anthropologists working across the country, we find in 2014 a strong reliance on store-bought consumer goods, and little evidence to attribute significant dietary contributions of bush foods in many locations, particularly those away from the resource-rich coastal regions.

Relatedly, we suggest that in discussions about customary practices, researchers should take seriously matters of intergenerational cultural change, as well as assertions about continuity. While senior generations in regions like Arnhem Land may well assert the relevance of customary practices in contemporary life, and indeed maintain such bush-oriented activities, we find little acknowledgement of the socioeconomic realities and cultural transformations occurring across generations in People on country and related publications.

Further, with regard to environmental work in northern Australia, we note Merlan's view that ranger programs 'in providing desirable kinds of work, draw on Indigenous interest and capacity but also deliberately undertake to transform consciousness and practice with respect to the environment' (Merlan 2013: 638). The nature of such transformation has been underexplored in the literature, which has tended to present a traditionalist interpretation of ranger 
activities. This is particularly accomplished through the pervasive dichotomisation of Western science and Indigenous knowledge within discussions about Indigenous involvement in environmental management activities. We now turn to an examination of this heuristic.

\section{Western science, Indigenous knowledge, and the intercultural}

Alongside the empirical question of Indigenous people's continuing reliance upon customary activity in the bush and the environmental impact of such activities, a key concept raised by many contributors to People on country which requires further analysis is the two-way concept. It is distinguished in the book and in much related literature as Western science and Indigenous knowledge, said to combine in environmental work in such a way as to 'contribute to the development of shared aspirations, approaches and outcomes' (Ens 2012: 45). This poses the issue of differentiating between these different ways. As Ens puts it in the book:

[I]dentification of each part is becoming increasingly important to legitimise work as two-way and not simply dominated by western ideology and approaches, with tokenistic Indigenous involvement and labour (2012: 47).

We endorse Ens's scepticism, and further ask: is the two-way concept meaningful theoretically, as well as practically? Does it not posit reified and/or valorised cultural domains in which tradition becomes a storehouse of customary knowledge, rather than an arena of Aboriginal sociality that is adapted and negotiated through interaction with the proximal people and institutions of Australian society (Trigger 1986, 1997)? How does it deal with intercultural interaction, change, creativity and improvisation? We caution here against confounding research with an ideology of traditionalism that explicitly or implicitly endorses strategic essentialism and an uncritical support for a politics of separatism.

While Altman's hybrid economy model can in principle be understood as a useful heuristic device to analyse a thoroughly interactive social world, the two-way approach can be seen to pitch an essentialised 
Aboriginal Gemeinschaft against a modern Australian Gesellschaft (concepts coined by the sociologist Tönnies in 1887, see Gelder 2005). In contrast to such an approach, we call for the examination of an intercultural relationality in which Indigenous social relations with the wider society are constrained yet pervasive in day-to-day life (Merlan 1998, 2013). We seek to avoid any unexamined 'postcolonial logic' (Kowal 2008) that, in the area of environmental work, may risk promoting a romanticisation of Aboriginal people as the 'new noble savages' (Langton 2013: 63).

Without dismissing the influence of Indigenous laws and customs on contemporary activities, we observe little empirical research on the actual role of what may be considered traditional knowledge in environmental work being undertaken among Indigenous people today. How do weed eradication programs, marine debris collection and burning practices with aerial incendiary devices draw on such traditional knowledge? Is the trope of customary knowledge meaningful or informative in describing the early dry season drops of incendiary devices from helicopters to create fire breaks on pastoral properties in return for carbon emission reduction funds? What ideological work do the words 'customary' or 'traditional' accomplish here?

A related issue is the question: Who or what drives such programs and environment-oriented activities? We note here the structural division of People on country into one part written by academics and another by Indigenous partners as facilitated by academics and other advisors. What is the nature of such whitefella facilitation? One chapter which specifically addresses this is provided in People on country by ecologist Emilie Ens, who points to 'differing perceptions of what work is and how it should be conducted' in Arnhem Land with reference to the failure of Indigenous rangers to follow through with projects in the absence of the ecologist (Ens 2012: 62). We are unsure where such 'differing perceptions' leave the conceptual proposition of 'dialectical interdependence' as advanced by Altman (2012: xix). In this case, whitefella supervisors were clearly central to the success of two-way activities. Where does this leave the concept of shared environmentalist sentiments? Is it not more accurate to understand such activities as little different from long-established patterns of Aboriginal engagement in sectors of the workforce via employment that becomes available through enterprises driven by Euro-Australian agencies? 
We also ask whether the two-way approach is meaningful and effectual politically. Is there a realistic expectation of continued state funding for environmental work in Indigenous communities? What assumptions is the expectation of such support premised on? Does the two-way approach risk marginalising or trivialising Indigenous contributions that are not strictly traditional, effectively positioning Working on Country as a form of positive discrimination, possibly even a romanticised kind of work-creation program? We note the homologies here with the historical employment of Indigenous people in lowwaged work arising in aspects of environmental management, such as the handling of dangerous chemicals, tackling of invasive species, and so on. With the idea of two-way customary environmentalism are we observing a shift of substance or rhetoric?

The two-way concept leaves us with questions about epistemology and the intellectual examination of intercultural identities, and about the meaning of keywords such as 'partners', 'participation', and 'interdependence'. In our view, it also risks leaving unaddressed how we might envisage the road to economic self-reliance based on environmental work for Indigenous people in rural and remote regions across Australia.

\section{Our observations}

During our ethnographic work in the Gulf Country (Trigger \& Martin), the Kimberley and southern Queensland (de Rijke), we have observed in all these locations a strongly articulated desire among Indigenous people to (re)connect and be involved with their country.

The idea of tradition figures sociopolitically and as a form of advocacy across all these settings, particularly in Indigenous engagements with the state. One example is the use of 'tradition' in grant applications and policy documents directed toward priorities such as the registration of Indigenous Protected Areas (IPAs). Such applications characteristically include information about clan estate organisation and Dreamings without specifying how such information relates to the pursuit of the priorities of an IPA. Indeed, it is hard to envisage how local clan estate organisation (in regions with this customary tenure system) or principles affiliating particular families of polity with specific areas (Sutton 2003: 206-31) could be meaningfully deployed 
towards contemporary land management priorities which typically require landscape-level solutions, for example directed towards the control of invasive species like rubber vine. It is even more difficult to envisage how Dreaming information and other esoteric religious knowledge might be relevant to this encounter with the state. This is not to suggest there is no addressing of land management in IPA discourses, but the reference to classical forms of land tenure and religious knowledge to leverage funding raises the question again of what ideological work the idea of 'tradition' is really doing here, as much for the state's policies and conceptions of the locus of Aboriginal culture in Australian society, as for self-conscious traditionalism among relevant Aboriginal individuals, families and organisations.

Likewise, across all these settings we find varied assessments and approaches to change. A question we may ask concerns the sources of traditional knowledge understood to be operationalised in land management work among Indigenous rangers or other Aboriginal people. We suggest such an inquiry would engage with Indigenous peoples' use of land claim and native title documents and other anthropological research, published and archival historical work, photos, maps, and so on. These sources of traditional knowledge are hardly contrary to achieving continuity of customary environmentalism. However, our point is that such issues are characteristically unaddressed in accounts of Indigenous knowledge. In our field sites, these dynamics certainly underline how traditional knowledge arises from mixed and contested histories of documentation as well as oral communications, invariably also prompted by economic drivers associated with heritage surveys, mining and other development project negotiations, native title claims and the like.

Work with fire presents an instructive example. In the Gulf Country, customary Indigenous traditions regarding the use of fire as a land management tool have been profoundly impacted by pastoralism, to the extent that many Aboriginal people perceive the late dry season burning preferred by some pastoralists as a traditional practice (see Martin 2013b: 75-6). Through investment in regional fire management, such Indigenous perceptions are changing, as the early dry season mosaic burning patterns of precolonial times are revived. But it is clear that such practices are recovered traditions (Hobsbawn 
\& Ranger 1983) rather than straightforwardly reinstituted ones, and it is the conditions driving such revival and the extent to which it is sustainable across the continent that require clear analysis.

We agree with Altman, Kerins and others that land and sea management and environmental work more broadly is an important concern for Aboriginal people. Like many across the political spectrum in Australia, we are encouraged by Indigenous people's embrace of such work and commitment to its stated goals where this occurs. In our view, environmental work may well contribute to healthier lives on country for those who manage to secure such positions. However, our corrective to reified ideas of customary knowledge is that this process should be recognised as driven by the realpolitik of achieving funding and related resources, laudable aims of assisting young people to find meaningful work and a potential disposition inclined as much towards embracing new forms of knowledge as reviving traditions.

\section{Conclusion}

In this chapter we have asked a number of questions about what we term 'customary environmentalism' in Australian Indigenous communities. We return here to the question which we see underlying much of the recent work by Altman and some others at CAEPR as to whether assumptions about tradition and culture, howsoever understood, are a viable basis for achieving economic self-reliance. If so, where, and how? We should note that this is a separate question from the acknowledged value of successfully asserted pride and symbolic recognition of a continuing Aboriginal identity in Australian society.

We suggest it is not adequate to posit environmental work across the country being informed by tradition without a clear appreciation of how this tradition is itself an expression of intercultural relationships and the potential leverage achieved through strategic essentialism. While superficially attractive to many, including some Indigenous people, the reification of customary environmental knowledge may well risk forcing Aboriginal people into the corner of 'a stateresourced and mandated project of "traditionalism"' (Martin 2009: 108) of the kind that has been noted in native title cases. In the context of programs of environmental work among Aboriginal people, this may occur through assumptions or implicit requirements that they 
mobilise and implement traditional knowledge as a pathway into modernity and economic development. This may well be fine and productive in regard to some places and in respect of certain aspects of knowledge of the country. But analyses will also usefully encompass how environmental work has as much to do with people looking for job opportunities and learning from professional scientists and others as it does with drawing on traditional knowledge.

An interesting question in this regard is whether non-Indigenous people could or should be employed together with Aboriginal people in environmental management programs (other than supervisory roles)? Related to the above is the question of whether environmental work for Indigenous people is to continue only or mainly in the more remote locations. Can there be Indigenous rangers working with nonIndigenous rangers in mixed communities and towns as well as cities like Sydney or Melbourne? We suggest the adequate study of Indigenous environmental work requires engagement with the broader context in which such work is situated, including empathetic attention to the nonIndigenous people and institutions involved (cf. Fache 2014).

Indigenous development remains a central challenge, and promise, of Australian Government policy. We see this challenge as the central preoccupation of much of Jon Altman's work over many years. In engaging with a key aspect of CAEPR's research for this chapter we note the empirical rigour and strength of the writing we have focused on. However, in our view, there is an unmistakeable element of utopianism in the approach we have critiqued. While that idealism is in some respects attractive and symbolically satisfying for those of us who are committed to supporting aspirations among Aboriginal people, we argue for a thorough examination and discussion of fundamental concepts underlying the idea of customary environmental work.

\section{References}

Altman JC (2012). Preface. In Altman JC \& Kerins S (eds), People on country: vital landscapes, Indigenous futures, The Federation Press, Sydney.

Altman JC \& Kerins S (eds) (2012). People on country: vital landscapes, Indigenous futures, The Federation Press, Sydney. 
de Rijke K (2013). Book review. People on country: vital landscapes, Indigenous futures. Altman JC \& Kerins S (eds). The Australian Journal of Anthropology 24(3):259-61.

Ens E (2012). Conducting two-way ecological research. In Altman JC \& Kerins S (eds), People on country: vital landscapes, Indigenous futures, The Federation Press, Sydney.

Fache E (2014). Caring for country, a form of bureaucratic participation. Conservation, development, and neoliberalism in Indigenous Australia. Anthropological Forum: A Journal of Social Anthropology and Comparative Sociology 24(3):267-86.

Gelder K (2005). Reading Stephen Muecke's ancient and modern: time, culture, and Indigenous philosophy. Australian Humanities Review 36 , July.

Hobsbawn E \& Ranger T (1983). The invention of tradition, Cambridge University Press, Cambridge.

Kowal E (2008). The politics of the gap: Indigenous Australians, liberal multiculturalism, and the end of the self-determination era. American Anthropologist 110(3):338-48.

Langton M (2013). The quiet revolution: Indigenous people and the resources boom, HarperCollins, Sydney.

Martin DF (2009). The governance of agreements between Aboriginal people and resource developers: principles for sustainability. In Altman JC \& Martin DF (eds), Power, culture, economy: Indigenous Australians and mining, CAEPR Research Monograph No. 30, ANU E Press, Canberra.

Martin R (2013a). Book review. People on country: vital landscapes, Indigenous futures. Altman JC \& Kerins S (eds). Australian Book Review 348:48-9.

Martin R (2013b). Sometime a fire: re-imagining elemental conflict in northern Australia's Gulf Country. Australian Humanities Review 55:67-91.

Merlan F (1998). Caging the rainbow: places, politics, and Aborigines in a north Australian town, University of Hawaii Press, Honolulu. 
Merlan F (2013). Theorizing relationality: a response to the Morphys. American Anthropologist 115(4):637-8.

O'Dea K (1984). Marked improvement in carbohydrate and lipid metabolism in diabetic Australian Aborigines after temporary reversion to traditional lifestyle. Diabetes 33(6):596-603.

Scelza BA, Bird DG \& Bliege Bird R (2014). Bush tucker, shop tucker: production, consumption, and diet at an Aboriginal outstation. Ecology of Food and Nutrition 53(1):98-117.

Sutton P (2003). Native title in Australia: an ethnographic perspective, Cambridge University Press, Cambridge.

Sutton P (2009). The politics of suffering: Indigenous Australia and the end of the liberal consensus, Melbourne University Publishing, Melbourne.

Trigger D (1986). Blackfellas and Whitefellas: the concepts of domain and social closure in the analysis of race relations. Mankind 16(2):99-117.

Trigger D (1997). Land rights and the reproduction of Aboriginal culture in Australia's Gulf Country. Social Analysis 41:84-106. 
This text is taken from Engaging Indigenous Economy: Debating diverse approaches, edited by Will Sanders, published 2016 by ANU Press, The Australian National University, Canberra, Australia. 